https://helda.helsinki.fi

\title{
Hysteresis and Fiscal Policy
}

\section{Engler, Philipp}

2018-08

Engler , P \& Tervala , J V S 2018 , ' Hysteresis and Fiscal Policy ' , Journal of Economic

Dynamics \& Control , vol. 93 , pp. 39-53 . https://doi.org/10.1016/j.jedc.2018.02.002

http://hdl.handle.net/10138/238272

https://doi.org/10.1016/j.jedc.2018.02.002

acceptedVersion

Downloaded from Helda, University of Helsinki institutional repository.

This is an electronic reprint of the original article.

This reprint may differ from the original in pagination and typographic detail.

Please cite the original version. 


\title{
Hysteresis and Fiscal Policy
}

\author{
Philipp Engler and Juha Tervala*
}

January 31, 2018

\begin{abstract}
Empirical studies support the hysteresis hypothesis that recessions have a permanent effect on the level of output. We analyze the implications of hysteresis for fiscal policy in a DSGE model. We assume a simple learning-by-doing mechanism where demand-driven changes in employment can affect the level of productivity permanently, leading to hysteresis in output. We show that the fiscal output multiplier is much larger in the presence of hysteresis and that the welfare multiplier of fiscal policy-the consumption equivalent change in welfare for one dollar change in public spending-is positive (negative) in the presence (absence) of hysteresis. The main benefit of accommodative fiscal policy in the presence of hysteresis is to diminish the damage of a recession to the long-term level of productivity and, thus, output.
\end{abstract}

Keywords: Fiscal policy, hysteresis, learning by doing, welfare

JEL classification: E62, F41, F44

${ }^{*}$ Contact: Philipp Engler, IMF; Juha Tervala (corresponding author), University of Helsinki, P.O. Box 17, 00014 University of Helsinki, Finland, juha.tervala@helsinki.fi. We are grateful for comments to Fredj Jawadi, Mathias Klein, George Kouretas, Athanasios Papadopoulos, Evi Pappa, Mathias Trabandt, two anonymous referees, conference participants at the 21st Annual International Conference on Macroeconomic Analysis and International Finance and the joint ifo-DIW-OFCE-CEPII conference in Berlin and seminar participants at the University of Bamberg. 


\subsection{Introduction}

The hysteresis hypothesis that recessions have a permanent effect on the level of output is supported by several empirical studies. Ball (2014) estimates the long-term effects of the global recession of 2008-2009 on potential output in 23 countries. He finds that most countries suffered from a hysteresis effect, as deviations of actual output from pre-recession trends lowered potential output substantially. Blanchard et al. (2015) analyze the effects of recessions over the past 50 years in 23 countries and find that roughly two-thirds of the countries suffered from hysteresis. After recessions, actual output remains low relative to pre-recession trends, even after the economy has recovered. Fatas and Summers (2016a) find empirical support for the presence of strong hysteresis effects of fiscal policy. Fiscal consolidations after the Great Recession have not only caused a temporary loss in output but also permanent damage to potential output.

Summers (2015) criticizes dynamic stochastic general equilibrium (DSGE) models and New Keynesian macroeconomics because they ignore hysteresis. He points out that in New Keynesian models, stabilization policy cannot affect the average level of output over time; it can affect only the amplitude of economic fluctuations. He argues that stabilization policy is not as essential if it cannot affect the average level of output over time. According to him, the study of stabilization policy without hysteresis "essentially abstracts away from most of what is important in macroeconomics." Yellen (2016) highlights that hysteresis and the possibility it might be reversed can have important implications for the conduct of fiscal policy.

Traditionally, modeling hysteresis relies on the labor market. Blanchard and Summers (1986) argue that a rise in cyclical unemployment increases long-term unemployment or unemployed workers may experience a fall in their skills, leading to a persistent or even a permanent fall in employment and output. Fatas and Summers (2016b) argue that one should think about a broader concept of hysteresis that allows a temporary downturn to affect productivity and capital accumulation dynamics, thereby creating a much stronger connection between recessions and long-term output. Reifschneider et al. (2015) and Anzoategui et al. (2016) indeed find that recessions cause damage to productivity and capital accumulation. Anzoategui et al. (2016) develop a New Keynesian DSGE model with endogenous total factor productivity (TFP) that allows for the costly development and adoption of new technologies. They find that, in the recent U.S. productivity slowdown, TFP declined by roughly 5 percentage points relative to the trend. The endogenous component explains 4.75 percentage points of the slowdown and most of the 7 percentage points decline in labor productivity. 
The main contribution of this paper is to analyze the implications of hysteresis for the conduct of fiscal policy in a New Keynesian DSGE model. In particular, we investigate the consequences of hysteresis for the output multiplier of fiscal policy and the welfare multiplier of fiscal policy, defined as the consumption equivalent change in welfare for one dollar change in public spending. The findings of Anzoategui et al. (2016) suggest that endogenous changes in TFP caused by a fall in demand is the most important factor of hysteresis. To model endogenous changes in TFP, we add a simple learningby-doing mechanism into the production function, following the formulation of Tervala (2013), based on the idea of Chang et al. (2002). They assume skill accumulation through past work experience, such that employment today affects future TFP. We assume, unlike Chang et al. (2002) and Tervala (2013), that fluctuations in employment can affect TFP quasi-permanently. We use a two-country model in order to have an entirely demand-driven source for a recession and assume that a foreign time preference shock drives the domestic economy into a recession.

Our first main finding is that the introduction of hysteresis-a hysteresislike response of productivity-raises the net present value fiscal multiplier (NVPM), the sum of output over a certain time horizon discounted at the steady state interest rate divided by public spending calculated in the same way, from 0.8 to 4.5 under the benchmark parameterization. A common argument against accommodative fiscal policy is that (short-term) fiscal output multipliers are low. However, the main benefit of fiscal policy in the presence of hysteresis is to limit, by reducing the depth of a recession, the damage of a recession to the long-term level of productivity and, thus, output. Consequently the NVPM is very large.

The most directly related paper is Rendahl (2016), who analyzes the efficacy of fiscal policy in a liquidity trap in a model with hysteresis-like movements in the unemployment rate. In his model, fiscal expansion lowers the unemployment rate both in the present and in the future. Consequently, the influence of demand on aggregate supply increases the fiscal multiplier, which he finds to be in the range of 0.8 to 1.8 . Our results are in line with Rendahl (2016); however, the influence of demand on aggregate supply through productivity seems to increase the efficacy of fiscal policy much more. Moreover, our results do not rely on the liquidity trap environment.

Our second main finding is that in the absence of hysteresis, the welfare multiplier of fiscal policy is negative; hysteresis, however, makes it positive. The welfare multiplier with hysteresis is 2.2 , even when public spending does not provide direct utility to households. So one dollar spent by the government raises domestic welfare by the equivalent of 2.2 dollars of private consumption. The reason for the positive welfare multiplier is that counter- 
cyclical fiscal policy diminishes the damage of a recession to the long-term level of private consumption. Rendahl (2016) finds that the welfare multiplier is at most 0.7 , when public spending is pure waste. He also finds that if the duration of a rise in public spending is short, relative to the duration of the liquidity trap, welfare multipliers turn negative. In our case, where the influence of demand on aggregate supply is modelled through productivity, welfare multipliers are always positive. Therefore, the view that accommodative fiscal policy does not necessarily increase welfare, even when fiscal output multipliers are large (see e.g. Bilbiie et al. 2014 and Mankiw and Weinzierl 2011), is not valid in the presence of hysteresis.

The rest of the paper is organized as follows. Section 2 introduces the model. Section 3 discusses the parameterization of the model. Section 4 studies the output and welfare multipliers of fiscal policy. Section 5 concludes the paper.

\section{Model}

We use a New Keynesian open-economy model with two countries: home and foreign. The size of the world population is normalized to 1 and a continuum of firms and households are indexed by $z \in[0,1]$. A fraction $n(1-n)$ of them are domestic (foreign).

\subsection{Households}

All households have identical preferences. The utility function of the representative domestic household is (if equations are symmetric across countries we present only domestic equations)

$$
U_{t}(z)=E_{t} \sum_{s=t}^{\infty} \beta^{s-t} \epsilon_{s}^{T P}\left[\log C_{s}-{\frac{\left(\ell_{s}(z)\right)^{1+\frac{1}{\varphi}}}{1+\frac{1}{\varphi}}}^{T}+\nu \log G_{s}\right],
$$

where $E$ is the expectation operator, $\beta$ is the discount factor, $\epsilon_{t}^{T P}$ is a time preference shock that affects the intertemporal substitution of households, $C_{t}$ is a private consumption index, $\ell_{t}(z)$ is the labor supply, $\varphi$ is the Frisch elasticity of labor supply, $G_{t}$ is a public consumption index, and $\nu$ is the weight of public consumption relative to private consumption. The private consumption index is

$$
C_{t}=\left[(\alpha n)^{\frac{1}{\rho}}\left(C_{t}^{h}\right)^{\frac{\rho-1}{\rho}}+(1-\alpha n)^{\frac{1}{\rho}}\left(C_{t}^{f}\right)^{\frac{\rho-1}{\rho}}\right]^{\frac{\rho}{\rho-1}}
$$


where $C_{t}^{h}$ and $C_{t}^{f}$, respectively, are indexes of domestic and foreign goods, $\alpha n(0<\alpha n<1)$ is the share of domestic goods in the consumption basket ( $\alpha>1$ captures the degree of home bias in consumption) and $\rho>0$ measures the elasticity of substitution between domestic and foreign goods (the crosscountry substitutability, for short). ${ }^{1}$ The public consumption indexes are identical to the private consumption ones.

The consumption indexes of the different types of domestic $C_{t}^{h}$ and foreign goods $C_{t}^{f}$ are

$$
C_{t}^{h}=\left[n^{-\frac{1}{\theta}} \int_{0}^{n}\left(c_{t}^{h}(z)\right)^{\frac{\theta-1}{\theta}} d z\right]^{\frac{\theta}{\theta-1}}, \quad C_{t}^{f}=\left[(1-n)^{-\frac{1}{\theta}} \int_{n}^{1}\left(c_{t}^{f}(z)\right)^{\frac{\theta-1}{\theta}} d z\right]^{\frac{\theta}{\theta-1}},
$$

where $c_{t}^{h}(z)\left(c_{t}^{f}(z)\right)$ is the consumption of differentiated domestic (foreign) good $\mathrm{z}$ by the domestic household and $\theta>1$ is the elasticity of substitution between goods produced in the same country (the within-country substitutability, for short).

The private demand functions for the domestic and foreign goods by domestic and foreign households are (the demand functions by governments are defined in an analogous way)

$$
\begin{gathered}
c_{t}^{h}(z)=\left[\frac{p_{t}^{h}(z)}{P_{t}^{h}}\right]^{-\theta}\left[\frac{P_{t}^{h}}{P_{t}}\right]^{-\rho} \alpha C_{t}, \\
c_{t}^{f}(z)=\left[\frac{p_{t}^{f}(z)}{P_{t}^{f}}\right]^{-\theta}\left[\frac{P_{t}^{f}}{P_{t}}\right]^{-\rho}\left[\frac{1-\alpha n}{1-n}\right] C_{t}, \\
c_{t}^{* h}(z)=\left[\frac{p_{t}^{* h}(z)}{P_{t}^{* h}}\right]^{-\theta}\left[\frac{P_{t}^{* h}}{P_{t}^{*}}\right]^{-\rho} \alpha^{*} C_{t}^{*}, \\
c_{t}^{* f}(z)=\left[\frac{p_{t}^{* f}(z)}{P_{t}^{* f}}\right]^{-\theta}\left[\frac{P_{t}^{* f}}{P_{t}^{*}}\right]^{-\rho}\left[\frac{1-\alpha^{*} n}{1-n}\right] C_{t}^{*} .
\end{gathered}
$$

$p_{t}^{h}(z)$ and $p_{t}^{f}(z)$ show, respectively, the domestic currency price of domestic and foreign goods. $P_{t}^{h}$ and $P_{t}^{f}$ are the price indexes that correspond to domestic and foreign aggregate consumption baskets $C_{t}^{h}$ and $C_{t}^{f}$. All price indexes are expressed in local currency terms, and foreign currency price

\footnotetext{
${ }^{1}$ The foreign consumption index is $C_{t}^{*}=\left[\left(\alpha n^{*}\right)^{\frac{1}{\rho}}\left(C_{t}^{* h}\right)^{\frac{\rho-1}{\rho}}+(1-\alpha n)^{\frac{1}{\rho}}\left(C_{t}^{* f}\right)^{\frac{\rho-1}{\rho}}\right]^{\frac{\rho}{\rho-1}}$, asterisks show consumption by the foreign household. Home bias in consumption requires $\alpha^{*}<1$.
} 
indexes are denoted with an asterisk. For instance, the foreign currency price of a domestic good is $p_{t}^{* h}$.

The domestic price indexes are as follows:

$$
\begin{gathered}
P_{t}^{h}=\left[n^{-1} \int_{0}^{n} p_{t}^{h}(z)^{1-\theta} d z\right]^{\frac{1}{1-\theta}}, \quad P_{t}^{f}=\left[(1-n)^{-1} \int_{n}^{1} p_{t}^{f}(z)^{1-\theta} d z\right]^{\frac{1}{1-\theta}} \\
P_{t}=\left[\alpha n\left(P_{t}^{h}\right)^{1-\rho}+(1-\alpha n)\left(P_{t}^{f}\right)^{1-\rho}\right]^{\frac{1}{1-\rho}} .
\end{gathered}
$$

The budget constraint of the domestic household, in nominal terms, is

$$
D_{t}=\left(1+i_{t}\right) D_{t-1}+w_{t} \ell_{t}-P_{t} C_{t}+\pi_{t}-P_{t} T_{t} .
$$

$D_{t}$ is nominal bonds, which pays one domestic currency in period $t+1$, held at the end of period $t, i_{t}$ is the nominal interest rate on bonds between $t-1$ and $t, w_{t}$ is the nominal wage, $\pi_{t}$ is the nominal profits/dividends of domestic firms, and $T_{t}$ is lump-sum taxes.

The domestic bond is the only internationally traded asset and its global asset market-clearing condition is $n D_{t}+(1-n) D_{t}^{*}=0$. The foreign bond $\left(F^{*}\right)$ that denominated in the foreign currency can be held only by the foreign household. Because the foreign country has only the representative household, the net supply of them is zero.

The budget constraint of the foreign household is

$$
\frac{D_{t}^{*}}{S_{t}}+F_{t}^{*}=\left(1+i_{t-1}\right) \frac{D_{t-1}^{*}}{S_{t}}+\left(1+i_{t-1}^{*}\right) F_{t-1}^{*}+w_{t}^{*} \ell_{t}^{*}-P_{t}^{*} C_{t}^{*}+\pi_{t}^{*}-P_{t}^{*} T_{t}^{*} .
$$

As e.g. in Bergin (2006), we assume a risk premium for the uncovered interest rate parity (UIP) that depends on the country's net external debt level. The risk premium forces the debt to converge back to zero in the long term. The UIP condition is

$$
\left(1+i_{t}\right)=\left(1+i_{t}^{*}\right) \frac{S_{t+1}}{S_{t}}+\psi\left(\exp \left(D_{t}\right)-1\right),
$$

where $\psi\left(\exp \left(D_{t}\right)-1\right)$ is the risk premium.

The household's optimality conditions are:

$$
\begin{gathered}
\beta\left(1+i_{t}\right) E_{t}\left(\frac{\epsilon_{t+1}^{T P} P_{t} C_{t}}{\epsilon_{t}^{T P} P_{t+1} C_{t+1}}\right)=1, \\
\ell_{t}(z)=\left(\frac{w_{t}}{C_{t} P_{t}}\right)^{\nu} .
\end{gathered}
$$

Equation (7) is the Euler equation for optimal consumption. Equation (8) governs the labor supply. 


\section{$1.2 \quad$ Firms}

Martin et al. (2015) show that severe recessions have sizable effects on the level of output relative to pre-recession trend and that even normal recessions have permanent, but smaller, effects. They also show that after normal recessions, the employment rate and total hours worked return to their pre-recession trends, whereas labor productivity (they do not analyze TFP) shows a highly persistent or even permanent fall. It does not show any signs, 6 years after the start of the recession, that it would start to converge back to its pre-recession trend. Anzoategui et al. (2016) find that endogenous changes in TFP explain most of the drop in labor productivity during and after the Great Recession. Motivated by these findings, we focus exclusively on hysteresis caused by endogenous changes in TFP and-in order to keep the model as simple as possible-ignore capital deepening and hysteresis in employment. Our way of modelling the influence of demand on aggregate supply only through TFP yields a realistic extent of hysteresis.

All firms produce a differentiated good. The production function is

$$
y_{t}(z)=a_{t}(z) \ell_{t}(z)
$$

where $y_{t}(z)$ is the total output of firm $z, a_{t}(z)$ is the level of TFP and $\ell_{t}(z)$ is the labor input used by the firm. The production function without capital and constant returns to labor imply that labor productivity is simply the level of TFP $\left(y_{t}(z) / \ell_{t}(z)=a_{t}(z) \ell_{t}(z) / \ell_{t}=a_{t}(z)\right)$.

We use a simple way of modeling hysteresis. Chang et al. (2002) assume a simple skill accumulation mechanism through learning by doing, in which the skill level accumulates over time depending on past employment and that the skill level raises the effective unit of labor supplied by the household. Following this, Tervala (2013) assumes that the level of TFP accumulates over time according to past employment. As in Tervala (2013), the level of TFP evolves according to the following log-linear equation:

$$
\hat{a}_{t}(z)=\phi \hat{a}_{t-1}(z)+\mu \hat{\ell}_{t-1}(z),
$$

where $0 \leq \phi \leq 1$ and $\mu$ are parameters. Percentage changes from the initial steady state are denoted by hats (for instance, $\hat{a}_{t}=d a_{t} / a_{0}$, where the subscript zero denotes the initial steady state). Equation (10) highlights that a change in the current employment changes the level of TFP in the next period, with an elasticity of $\mu$. The change in the level of TFP may not be permanent, because the level of TFP depreciates over time at the rate of $1-\phi$. If $\phi=1$, then the level of TFP shifts permanently when employment changes. In this case, temporary shocks have a permanent effect on the equilibrium level of output, meeting the requirement for hysteresis. If $\phi<1$, 
then temporary shocks have a persistent, but not permanent, effect on the level of TFP and output. We set $\phi=0.99$, which implies that the response of TFP is quasi-permanent. Reifschneider et al. (2015) use a quite similar way of modelling hysteresis, as they assume that TFP today depends on its value in the previous period and the difference between the natural rate of unemployment and the actual rate of unemployment in the previous period. In addition, they assume a hysteresis-like response of TFP by assuming $\phi<1$.

Figure 1, which shows U.S. TFP and GDP in 2000-2015, indicates some support for our view. TFP fell during the Great Recession and GDP and TFP do not show signs that they would have started to converge back to their pre-recession trends.

The domestic firm maximizes profits

$$
\pi_{t}(z)=p_{t}^{h}(z) y_{t}^{d}(z)-w_{t} \ell_{t}(z),
$$

taking account the production function (9) and the demand curve for its products

$y_{t}^{d}(z)=\left[\frac{p_{t}^{h}(z)}{P_{t}^{h}}\right]^{-\theta}\left[\frac{P_{t}^{h}}{P_{t}}\right]^{-\rho} \alpha n\left(C_{t}+G_{t}+\left[\frac{p_{t}^{h}(z)}{S_{t} P_{t}^{* h}}\right]^{-\theta}\left[\frac{S_{t} P_{t}^{* h}}{S_{t} P_{t}^{*}}\right]^{-\rho}(1-n) \alpha^{*}\left(C_{t}^{*}+G_{t}^{*}\right)\right.$.

Under flexible prices, the domestic firm maximizes profits, equation (11), with respect to $p_{t}^{h}(z)$. The solution is

$$
p_{t}^{h}(z)=\frac{\theta}{\theta-1} \frac{w_{t}}{a_{t}(z)} .
$$

Following Calvo (1983), each firm may reset its price only with a probability of $1-\gamma$ in any given period, independent of the time passed since the last price adjustment. The domestic firm seeks to maximize the discounted present value of expected real profits

$$
\max _{p_{t}^{h}(z)} V_{t}(z)=E_{t} \sum_{s=t}^{\infty} \gamma^{s-t} Q_{t, s} \frac{\pi_{s}(z)}{P_{s}}
$$

where $\zeta_{t, s}$ is a stochastic discount factor between periods $t$ and $s$. The solution is

$$
p_{t}^{h}(z)=\frac{\theta}{\theta-1} \frac{E_{t} \sum_{s=t}^{\infty} \gamma^{s-t} \zeta_{t, s} Q_{s} \frac{w_{s}}{a_{s}(z)}}{E_{t} \sum_{s=t}^{\infty} \gamma^{s-t} \zeta_{t, s} Q_{s}}
$$

where

$$
Q_{s}=\left(\frac{1}{P_{s}^{h}}\right)^{-\theta}\left(\frac{P_{s}^{h}}{P_{s}}\right)^{-\rho} \alpha n\left(\frac{C_{s}+G_{s}}{P_{s}}\right)+\left(\frac{1}{S_{s} P_{s}^{* h}}\right)^{-\theta}\left(\frac{P_{s}^{h}}{S_{s} P_{s}^{*}}\right)^{-\rho}(1-n) \alpha^{*}\left(\frac{C_{s}^{*}+G_{s}^{*}}{P_{s}}\right) .
$$


The log-linear version of equation (13) is a handy way to interpret it

$$
\hat{p}_{t}^{h}(z)=\beta \gamma E_{t} \hat{p}_{t+1}^{h}(z)+(1-\beta \gamma)\left(\hat{w}_{t}-\hat{a}_{t}(z)\right) .
$$

The change in the optimal price is the weighted average of the changes in current and future nominal marginal costs. A fall in the level of productivity raises the optimal price.

\subsection{Fiscal and Monetary Policy}

We assume the simplest possible way to model public spending: taxes are non-distortionary, as in Rendahl (2016), and the government budget is balanced. The government budget constraint, in per-capita and real terms, is expressed as

$$
T_{t}=G_{t}
$$

We assume that public spending follows an exogenous AR (1) process

$$
\hat{G}_{t}=\rho^{G} \hat{G}_{t-1}+\varepsilon_{t}^{G},
$$

where $\rho^{G} \in[0,1]$ and $\varepsilon_{t}^{G}$ is a white-noise process with zero mean that represents an unanticipated change in public spending.

Furman (2016) argues that the new view of fiscal policy is that fiscal policy is a beneficial complement to monetary policy when low interest rates limit conventional monetary policy. DeLong and Summers (2012) find that even a small amount of hysteresis makes expansionary fiscal policy very beneficial and even likely to be self-financing at the zero lower bound. Our intention is to analyze whether hysteresis, which seems to also be relevant in normal recessions, renders accommodative fiscal policy beneficial also outside the zero lower bound. Therefore, the central bank does not face the zero lower bound.

The use of the standard Taylor rule implies that the model must be stationary. A hysteresis-like response of productivity implies that the model is "quasi-non-stationarity". Therefore, we assume a pure inflation targeting rule. The central bank adjusts the interest rate in response to the deviations of inflation from the zero inflation target, according to a log-linear interest rate rule with interest rate smoothing:

$$
\hat{\imath}_{t}=\left(1-\mu_{1}\right) \mu_{2} \Delta \hat{P}_{t}+\mu_{1} \hat{\imath}_{t-1},
$$

where coefficients $\mu_{1}$ and $\mu_{2}$ are non-negative, and $\Delta$ is the first difference operator. 


\subsection{Symmetric Equilibrium}

The consolidated budget constraint of the home economy is derived with equations (4), (11) and $(14)^{2}$

$$
D_{t}-\left(1+i_{t}\right) D_{t-1}=p_{t}^{h}(z) y_{t}(z)-P_{t} C_{t}-P_{t} G_{t} .
$$

We log-linearize the model around a symmetric steady state where initial net foreign assets are zero. For simplicity, public spending is zero in the initial steady state and the initial level of productivity is normalized to one. Equations (8), (9) and (12) imply that the initial level of employment is

$$
\ell_{0}(z)=y_{0}=C_{0}=\left(\frac{\theta-1}{\theta}\right)^{\frac{1}{1+\frac{1}{\nu}}}
$$

Equilibrium is a sequence of variables that clear the goods and labor markets in both countries every period, while satisfying pricing rules and intertemporal budget constraints.

\section{Parameter Values}

Periods represent quarters and the discount factor $(\beta)$ is set to 0.99 . The relative size of the home country $(n)$ is set to 0.5 . The home bias parameter in domestic consumption $(\alpha)$ is set to 1.5. This implies that the import-to-GDP ratio $(1-\alpha n)$ is equal to 0.25 . This matches with the average import-to-GDP ratio in the OECD countries (World Bank 2016). We assume that the ratio is identical in both countries, consequently $\alpha^{*}$ is set to 0.5 . In a survey, Keane and Rogerson (2012) find that the Frisch elasticity of labor supply $(\varphi)$ is at the macro level in the range of 1 to 2 . We set it to 2 . Our choice is influenced by the fact that with this parameter value the size of the cumulative fiscal multipliers are consistent with the empirical evidence. The baseline value of the weight of public consumption to relative private consumption $(\nu)$ is set to 0.4, following Song et al. (2012). They argue that the parameter measures the efficiency in the provision of public goods. Since the welfare multipliers of fiscal policy are sensitive to changes in this parameter value, we vary it in the 0 to 1 range. The within-country substitutability $(\theta)$ is set to 9 , as in Gali (2015b). The cross-country substitutability $(\sigma)$ is set to 1.5 , which is a widely used in international macroeconomics and is consistent with Dong (2012).

\footnotetext{
${ }^{2}$ The foreign equation is $\frac{n}{1-n} \frac{D_{t}}{S_{t}}-\left(1+i_{t}\right) \frac{n}{1-n} \frac{D_{t-1}}{S_{t}}=p_{t}^{* f}(z) y_{t}^{*}(z)-P_{t}^{*} C_{t}^{*}$.
} 
The risk premium parameter in UIP $(\psi)$ is set to 0.004, based on Bergin (2006). We set the price rigidity parameter $(\gamma)$ to 0.75 , which is in line with the estimates of Rabanal and Tuesta (2010). Coefficients for the monetary policy rule are standard: the degree of interest smoothing $\left(\mu_{1}\right)$ is set to 0.79 , based on Clarida et al. (2000) and the inflation coefficient is set to 1.5, based on Taylor (1993).

We assume that a time preference shock follows an AR (1) process

$$
\hat{\epsilon}_{t}^{T P}=\rho^{T P} \hat{\epsilon}_{t-1}+\hat{\varepsilon}_{t}^{T P} .
$$

The persistence of a time preference shock $\left(\rho^{T P}\right)$ is set to 0.75 , as in Bodenstein et al. (2009). We would like to have an external and entirely demand-driven source for a domestic recession. Therefore, we assume that a foreign time preference shock $\left(\hat{\varepsilon}^{* T P}\right)$ drives the domestic economy into a recession. We set it to -5 . This causes roughly a one percent fall in domestic output without fiscal expansion. The persistence of fiscal shocks $\left(\rho^{G}\right)$ is set to 0.75 , based on the findings of Iwata (2013). We assume that the size of a domestic fiscal shock $\left(\hat{\varepsilon}_{t}^{G}\right)$ is $0.5 \%$ of initial GDP.

We analyze the effects of fiscal policy during recessions and, consequently, we set the persistence of the changes in the level of TFP $(\phi)$ such that recessions have hysteresis or hysteresis-like effects on TFP and, thus, output. As discussed earlier, hysteresis requires that $\phi$ is one. We, however, set $\phi$ to 0.99 for computational reasons. This generates a hysteresis-like response of TFP, but it, and the economy, eventually converge back to the initial steady state. Therefore, our results can be seen as an approximation to models with truly permanent effects. Reifschneider et al. (2015) use the same approach and argue that although deep recessions can have a persistent effect on labor supply, they do not change fundamental determinants of longer-term conditions in the labor market. The same can be argued about TFP.

A key parameter is the elasticity of TFP with respect to employment $(\mu)$, as it affects the extent of hysteresis. Chang et al. (2002) find the value of 0.11 , which we use. DeLong and Summers (2012) examine the limited evidence on the extent of hysteresis and argue that the plausible range of their hysteresis parameter-a proportional reduction in potential output from a temporary downturn-is between zero and 0.2. Rawdanowicz et al. (2014) analyze empirically the hysteresis parameter-the effect of one percentage point of the negative output gap on reducing potential output-and find a value of 0.1 for the U.S. and 0.3 for the euro area. In our model, the proportional reduction in output in the 20th period, when a foreign time preference shock has, in practice, died away and prices have adjusted, to first-period output is $0.13 .^{3}$

\footnotetext{
${ }^{3}$ The average without fiscal expansion in the home and foreign country.
} 
So the parameterization generates a realistic extent of hysteresis. ${ }^{4}$

\section{$3 \quad$ Fiscal Policy in a Recession}

\subsection{Output and Welfare Multipliers}

The main contribution of our paper is to analyze the consequences of hysteresis for the output and welfare multipliers of fiscal policy. Empirical studies often measure the effectiveness of fiscal policy as the cumulative output multiplier (CM), which is defined as the cumulative change of output over the cumulative change of fiscal policy (see e.g. Gechert and Rannenberg (2014)): $C M=\sum_{h} d Y_{t+h} / \sum_{h} d G_{t+h}$. In our model, a foreign time preference shock drives the home economy into a recession and we analyze the adjustment of two economies with and without expansionary domestic fiscal policy. The cumulative output multiplier is calculated as the difference of the cumulative change in output in case with fiscal expansion (denoted by superscript $F E$ ) and without fiscal expansion (denoted by superscript $W F E$ ), over the cumulative change of fiscal policy:

$$
C M=\frac{\sum_{h} \hat{Y}_{t+h}^{F E}-\sum_{h} \hat{Y}_{t+h}^{W F E}}{\sum_{h} \hat{G}_{t+h}^{F E}} .
$$

Several theoretical studies, following the work of Uhlig (2010), calculate the net present value fiscal multiplier (NPVM), which is the sum of output over a certain time horizon discounted at the steady state interest rate divided by public spending calculated in the same way. In our case NPVM is

$$
N P V M=\frac{\sum_{s=t}^{h} \beta^{s-t} \hat{Y}_{s}^{F E}-\sum_{s=t}^{h} \beta^{s-t} \hat{Y}_{s}^{W F E}}{\sum_{s=t}^{h} \beta^{s-t} \hat{G}_{s}^{F E}} .
$$

Sims and Wolff (2014) and Rendahl (2016) define the welfare multiplier of fiscal policy as the change in aggregate welfare-in consumption equivalent terms-for a one unit change in public spending. Following the idea of Schmitt-Grohe and Uribe (2007), we first calculate the welfare effect of fiscal policy as a percentage of consumption that households are willing to pay for policy A-now the fiscal expansion case-to remain as well off in the policy A case as in case of alternative policy B-now the case without fiscal expansion. Second, then we divide this by the change in public spending.

\footnotetext{
${ }^{4}$ We run the model using the algorithm of Klein (2000) and McCallum (2001).
} 
Let $U_{t}^{W F E}$ denote welfare in case without fiscal expansion, and let $\left\{C_{s}^{W F E}, G_{s}^{W F E}, \ell_{s}^{W F E}(z)\right\}_{s=t}^{\infty}$ denote the associated private and public consumption and labor supply paths: ${ }^{5}$

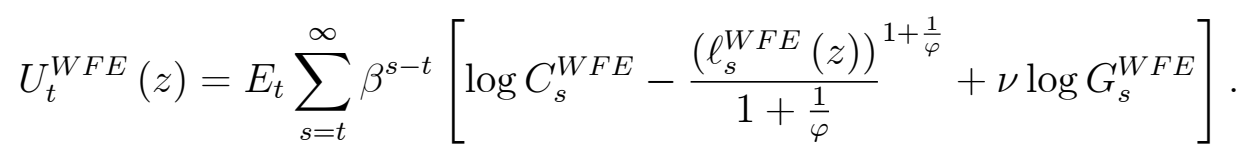

The welfare benefit of fiscal expansion relative to the case without fiscal expansion, denoted by $\lambda_{t}$, is measured as the fraction of initial consumption that the domestic household would be willing to pay-assuming that labor supply is held constant-to be as well off in the fiscal expansion case as in the case without fiscal expansion. Let $U_{t}^{F E}$ be the welfare obtained in case without fiscal expansion. It can be written using the definition of $\lambda_{t}$ as follows:

$$
\begin{aligned}
U_{t}^{F E} & =E_{t} \sum_{s=t}^{\infty} \beta^{s-t}\left[\log \left(\left(1+\lambda_{t}\right) C_{s}^{W F E}\right)-{\left.\frac{\left(\ell_{s}^{W F E}(z)\right)^{1+\frac{1}{\varphi}}}{1+\frac{1}{\varphi}}+\nu \log G_{s}^{W F E}\right]}=\frac{1}{1-\beta} \log \left(1+\lambda_{t}\right)+U_{t}^{W F E} .\right.
\end{aligned}
$$

Solving for $\lambda_{t}$ and multiplying the equation with 100 to express the welfare benefit as the percentage of consumption we obtain

$$
\lambda_{t}=100 \times\left[\exp (1-\beta)\left(U_{t}^{F E}-U_{t}^{W F E}\right)-1\right] .
$$

Substituting the first-order approximations of the utility function to (15) yields

$$
\begin{aligned}
\lambda_{t}= & 100 \times\left[\operatorname { e x p } \left(( 1 - \beta ) \left(\sum_{s=t}^{\infty} \beta^{s-t}\left(\hat{C}_{s}^{F E}-\left(\ell_{0}(z)\right)^{1+1 / \varphi} \hat{\ell}_{s}^{F E}+\nu \hat{G}_{s}^{F E}\right)\right.\right.\right. \\
& \left.\left.-\left(\sum_{s=t}^{\infty} \beta^{s-t}\left(\hat{C}_{s}^{W F E}-\left(\ell_{0}(z)\right)^{1+1 / \varphi} \hat{\ell}_{s}^{W F E}+\nu \hat{G}_{s}^{W F E}\right)\right)\right)-1\right]
\end{aligned}
$$

Equation (16) shows that the welfare benefit of fiscal expansion is the sum of welfare benefits relative to the case without fiscal expansion discounted at the steady state interest rate. The welfare multiplier (WM) is the welfare benefit divided by public spending discounted in the same way:

$$
W M_{t}=\frac{\lambda_{t}}{\sum_{s=t}^{h} \beta^{s-t} \hat{G}_{s}}
$$

\footnotetext{
${ }^{5}$ The calculation of the welfare multiplier is partly based on Ganelli and Tervala (2016). There are no time preference shocks in the home country. Therefore, we can normalize $\epsilon$ to one in the welfare calculus.
} 
Equation (17) measures the consumption equivalent change in welfare for one dollar change public spending.

\subsection{Transmission of Shocks without Hysteresis}

Figure 2 plots the dynamic effects of a foreign time preference shock on key variables in cases without hysteresis $(\mu=\phi=0)$. The horizontal axes show time and the vertical axes typically show percentage deviations from the initial steady state. The response of inflation is expressed as percentage point deviations in annual terms. In addition, the difference between the response of domestic consumption in cases without fiscal expansion and with fiscal expansion would be hard to see. Therefore, Figure 2(b) shows the difference between the response of domestic consumption in cases without fiscal expansion and with fiscal expansion $\left(\hat{C}_{t}^{W F E}-\hat{C}_{t}^{F E}\right)$. The real exchange rate, shown in Figure $2(\mathrm{~g})$, is $S_{t} P_{t}^{*} / P_{t}$. The domestic terms of trade, plotted in Figure 2(h), is the ratio of domestic export prices to domestic import prices. Changes in bond holdings of domestic households and public spending, whose initial values are zero, are expressed as percent deviations from initial steady state (SS) output. The solid lines depict the case without fiscal expansion, while the dashed lines depict the case in which domestic public spending is increased by $0.5 \%$ of initial output.

\begin{tabular}{|c|c|c|c|c|}
\hline Cumul. & Net present & Welf & are multi & blier \\
\hline \multicolumn{4}{|c|}{ Without hysteresis } & $\nu=1$ \\
\hline 0.7 & 0.8 & -1 & -0.6 & -0.02 \\
\hline \multicolumn{5}{|c|}{ With hysteresis } \\
\hline 1.4 & 4.5 & 2.2 & 2.6 & 3.2 \\
\hline
\end{tabular}

A strong foreign time preference shock causes a reduction in foreign consumption and labor supply, and thus affecting aggregate demand negatively. These induce a severe recession in the foreign country. Foreign demand for domestic goods falls and the home country experiences an export-driven recession. A recession in both countries induces deflation. However, the recession is deeper in the foreign country and, consequently, deflation is stronger in the foreign country. The real exchange rate of the home country appreciates, as shown in Figure 2(g).

An increase in the relative supply of domestic goods causes an improvement in the domestic terms of trade. This increases domestic consumption. A decrease in the foreign bond holdings of domestic households causes a negative wealth effect on labor supply and an increase in long-term output. 
Table 1 shows the multipliers of fiscal policy. The cumulative output multiplier is calculated using 16 quarters. NPVM and the welfare multiplier are calculated using 2,000 periods. Our baseline value for the weight of public consumption is 0.4 , but Table 1 also shows the welfare multipliers in cases in which $\nu=0$ and $\nu=1$.

Figure 2(a) shows that a domestic fiscal shock causes an increase in domestic output relative to the case without fiscal expansion. Table 1 shows that the cumulative output multiplier is 0.7 and the net present value fiscal multiplier is somewhat larger (0.8). Our results regarding short-term output multipliers are within the range of the empirical estimates of Gechert and Rannenberg (2014) and Ramey and Zubairy (2016). In addition, our results are in line with Kilponen et al. (2015), who employ fifteen DSGE models to estimate the size of short-term fiscal multipliers.

The welfare multiplier in the baseline case is -0.6: A one dollar increase in domestic public spending yields the welfare loss that corresponds to a 0.6 dollars fall in domestic private consumption, i.e. domestic households are willing to pay 0.6 dollars to avoid a one dollar rise in public spending. An increase in public consumption increases welfare through its direct effect on utility. This is, however, more than offset by negative effects. Figure 2(b) shows that private consumption falls because of higher taxes, relative to the case without fiscal expansion. In addition, a rise in public spending increases labor supply, relative to the case without fiscal expansion. Table 1 shows that the welfare multiplier becomes practically zero when public consumption yields as much utility as private consumption $(\nu=1)$.

In the absence of hysteresis, our model is very similar to Ganelli and Tervala (2016), who find that a rise in public consumption spending reduces welfare, unless the weight of public consumption is larger than the weight of private consumption in the utility function. Our welfare results are fully consistent with their findings.

\subsection{Transmission of Shocks with Hysteresis}

Figure 3 displays the responses of the main variables to a foreign time preference shock in the presence of hysteresis $(\mu=0.11$ and $\phi=0.99)$. It does not show inflation, but they behave similar to the previous case. Instead Panels (e) and (f) of Figure 3 show the changes in TFP. Figure 4 shows domestic output in the absence and presence of hysteresis and with and without fiscal expansion.

A foreign time preference shock causes a recession in both countries. A fall in employment induces a deterioration in the level of productivity, shown in Figures 2(e) and 2(f). The ratio of the peak deviation in productivity 
from the initial steady state to the peak deviation in output is 0.28 (a one percent fall in output causes a $0.28 \%$ fall in productivity) ${ }^{6}$ According to Conference Board (2016) data and our calculations on projections for GDP and productivity, shown in Figure 1, the ratio of the deviation of actual productivity from pre-recession trend to the deviation of actual output from pre-recession trend in the U.S. in 2009 was $0.26 .^{7}$ This suggests that the parameterization generates a realistic relationship between recessions and productivity.

A decline in productivity implies that the fall in domestic and foreign output in the presence of hysteresis is much more persistent than in the absence of hysteresis. The solid line of Figure 3(a) shows that without fiscal expansion, domestic output in the 20th period remains much below the initial level, even if the foreign shock has died away and the negative wealth effect tends to increase labor supply. A temporary demand-driven recession, which causes a fall in employment, deteriorates the equilibrium level of output by causing a fall in productivity. For the sake of comparison, in the absence of hysteresis and fiscal expansion, domestic output is above the initial level in the 20th period due to the negative wealth effect on the labor supply.

Figure 3(a) shows that in the case with fiscal expansion, the fall in domestic output is smaller. In the short term, fiscal expansion stimulates demand, but the benefits of fiscal expansion last much longer than the demand effect. In the case with fiscal expansion, a fall in employment is smaller and, consequently, the level of productivity deteriorates less, as shown in Figure $3(\mathrm{e})$. Thus the effect of fiscal expansion on productivity is positive which implies that the long-term level of output is higher. This implies much higher long-term output multipliers.

Fatas and Summers (2016a) find that fiscal consolidations after the Great Recession caused both a temporary loss in output and permanent damage to potential output. Standard DSGE models are unable to explain permanent output losses, whereas our model can explain the persistent or even permanent effects of fiscal policy on potential output. The idea that fiscal policy can affect TFP is not new, but the dominant view focuses exclusively on the consequences of the composition of public spending and taxation on TFP growth in the long term (see Everaert et al. 2015 and IMF 2015). In a rare paper, Linnemann et al. (2016) analyze the effects of fiscal policy on labor productivity from a business-cycle perspective and find that a positive spending shock increases labor productivity.

\footnotetext{
${ }^{6}$ In comparison, in Reifschneider et al. (2015) the ratio is roughly 0.1 .

${ }^{7}$ According to Conference Board (2016) data and our calculations, shown in Figure 4, the same ratio in the euro area in 2014 was 0.24 .
} 
Table 1 shows that the cumulative output multiplier is 1.4 in the presence of hysteresis. IMF (2012) finds that the cumulative output multiplier of a positive spending shock in the case of a negative output gap is 1.2. Auerbach and Gorodnichenko (2012) find that fiscal multipliers are between 1 and 1.5 in recessions. So our result is in the range of empirical estimates that are relevant for the question at hand. Table 1 also shows that the NPVM (4.5) is considerably greater than the cumulative multiplier (1.4). Figure 3(j) illustrates that after 20 periods, public spending has, in practice, returned to zero. However, the difference in domestic outputs, shown in Figure 3(a), depending on whether public spending is increased or not, is notable.

A typical argument against accommodative is that fiscal multipliers are low. Ramey and Zubairy (2016) argue that if fiscal multipliers are below unity, that implies that fiscal expansion does not stimulate private activity and that fiscal consolidation cannot do much harm to the private sector. The results of our paper suggest that the main benefit of fiscal expansion in a recession is to mitigate the adverse consequences of a recession for the long-term level of output. Consequently, the focus on short-term output multipliers as the main indicator of the effectiveness of fiscal policy in a recession may be misleading. In addition, Figure 3(b) shows that a rise in public spending-in the presence of hysteresis-increases private consumption in the medium and long term, relative to the case without fiscal expansion. The crowding-out of private consumption is a short-lived phenomenon.

Rendahl (2016) studies the effectiveness of fiscal policy in a liquidity trap using a model with persistent-hysteresis-like-movements in the unemployment rate. He finds that a rise in public spending lowers the unemployment rate in the present and in the future. Therefore, the influence of demand on aggregate supply through unemployment increases the fiscal output multiplier, which he finds to be in the range of 0.8 to 1.8 . Our results are in line with Rendahl (2016), but they suggest that the influence of demand on aggregate supply through productivity seems to increase output multipliers much more.

In our model, the NPVM is considerably higher in the presence of hysteresis (4.5) than in the absence of it (0.7). Uhlig (2010) argues that fiscal policy has potentially drastic long-term consequences. In his model a deficitfinanced rise in public spending stimulates output in the short term. The tax increases necessary to repay the increased public debt then hamper the economy considerably. We acknowledge that our model's limitation is that taxes are non-distortionary. Our model, however, shows that the potential long-term benefits of accommodative fiscal policy during recessions can be substantial due to hysteresis that is ignored in DSGE macroeconomics.

In the presence of hysteresis, Table 1 shows that the welfare multiplier is 
above 2 , even if public spending is pure waste $(\nu=0)$. In the baseline case $(\nu=0.4)$, the welfare multiplier is 2.6 , implying that one dollar spent by the public raises domestic welfare by the equivalent of 2.6 dollars of private consumption. An increase in domestic public spending reduces domestic private consumption in the short term because of higher taxes. After a while, the higher tax burden ends. As mentioned, a key benefit of fiscal expansion is that it limits the damage of a recession to long-term output. Therefore, a rise in public spending increases domestic private consumption relative to the case without fiscal expansion, as shown in Figure 3(b). The positive effect of fiscal expansion on private consumption in the medium and long term explains the positive welfare multiplier.

Rendahl (2016) finds that the welfare multiplier is in the range of -0.4 and 0.7 in cases where public spending does not provide direct utility to households. He shows that if the duration of a rise in public spending is short, relative to the duration of liquidity trap, the welfare multipliers are negative. In Section 4.4, we analyze the sensitivity of our welfare results with respect to the persistence of a fiscal shock and find different results.

Woodford (2011) shows the output multiplier in New Keynesian models depends crucially on monetary policy. He shows that the output multiplier can be well in excess of one at the zero lower bound. In this case, a rise in public consumption, which provides direct utility to households, which partially fills the output gap that arises from the inability to lower interest rates, increases welfare, because it does not crowd out private consumption. Bilbiie et al. (2014) find that, when public spending does not provide direct utility, expansionary fiscal policy is by and large welfare decreasing. Our paper highlights that in the presence of hysteresis, fiscal expansion increases welfare considerably, even if the central bank does not face the zero lower bound.

\subsection{Robustness Checks}

\subsubsection{Varying Key Parameters}

First, we check the sensitivity of the main results to changes in key parameter values. Chetty et al. (2013) claim that in macro models the Frisch elasticity should be set to 0.5. Table 2 shows multipliers in case where it is set to 0.5 ; the numbers in parentheses show the baseline results. Table 2 shows that the welfare multipliers are always negative in the absence of hysteresis, even if the output multipliers change quantitatively. The reason for the decrease in the output multipliers, compared with the baseline case, is the weaker response of the labor supply to the increase in demand. The finding that 
the welfare multiplier of fiscal policy is negative in the absence of hysteresis is robust to changes in the Frisch elasticity. In the presence of hysteresis, the output and welfare multipliers both fall considerably when the Frisch elasticity is reduced to 0.5 .

Table 2: Multipliers with a low Frisch elasticity Cumul. Net present Welfare multiplier multiplier value multipl. $\quad \nu=0 \quad \nu=0.4 \quad \nu=1$

Without hysteresis

\begin{tabular}{ccccc}
\hline $0.4(0.7)$ & $0.5(0.8)$ & $\begin{array}{c}-1(-1) \\
\text { With hysteresis }\end{array}$ & $-0.6(-0.6)$ & $-0.01(-0.02)$ \\
\hline $0.9(1.4)$ & $2.9(4.5)$ & $1.1(2.2)$ & $1.5(2.6)$ & $2.0(3.2)$ \\
\hline
\end{tabular}

Second, we analyze the sensitivity of our main results to changes in other key parameter values in the presence of hysteresis. Table 3 presents multipliers in the presence of hysteresis with row 1 replicating the baseline result. The second column shows the parameters used in the sensitivity analysis and the respective values of the baseline parameterization are shown in brackets.

\begin{tabular}{c|c|cccc}
\multirow{2}{*}{$\begin{array}{c}\text { Table 3: Varying Key Parameters in the Presence of Hysteresis } \\
\text { Row }\end{array}$} & Parameter & $\begin{array}{c}\text { Cumul. } \\
\text { multipl. }\end{array}$ & NPVM & $\begin{array}{c}\text { Welfare Multiplier } \\
(\nu=0)\end{array}$ & $\begin{array}{c}\text { M } \\
(\nu=0)\end{array}$ \\
\hline 1 & Baseline & 1.4 & 4.5 & 2.2 & 2.6 \\
\hline 2 & $\mu=0.06(0.11)$ & 1.1 & 2.9 & 0.8 & 1.2 \\
\hline 3 & $\mu=0.15(0.11)$ & 1.6 & 5.8 & 3.2 & 3.6 \\
\hline 4 & $\phi=0.96(0.99)$ & 1.3 & 2.3 & 0.3 & 0.7 \\
\hline 5 & $\phi=0.8(0.99)$ & 1.0 & 1.2 & -0.7 & -0.3 \\
\hline 6 & $\sigma=3.0(1.5)$ & 1.3 & 4.5 & 2.6 & 3.0 \\
\hline 7 & $\rho^{G}=0.9(0.75)$ & 1.2 & 4.4 & 2.2 & 2.6 \\
\hline 8 & $\rho^{G}=0.6(0.75)$ & 1.5 & 4.6 & 2.2 & 2.6 \\
\hline \hline
\end{tabular}

Rows 2-5 show modifications of the properties of the production function. In row 2 , the elasticity of productivity with respect to employment, $\mu$, is reduced from the baseline value of 0.11 to 0.06 . A lower value of $\mu$ implies a weaker effect of employment changes on productivity. This reduces the cumulative output multiplier from 1.4 to 1.1 and the NPVM from 4.5 to 2.9. The welfare multipliers fall but remain positive. Chang et al. (2002) find estimates for $\mu$ of 0.11 and 0.15 . This suggests that for realistic values of $\mu$, high output and welfare multipliers are reasonable. Row 3 shows multipliers in case where $\mu$ is increased to 0.15 . In this case, the ratio of the peak decline in productivity to the peak decline in output increases from 0.28 to 
0.37. This is much higher than the observed ratio during the Great Recession in the U.S. (0.26). So this alternative parameterization may overestimate the effect of a recession and fiscal policy on productivity.

In rows 4 and 5 , the persistence of the level of productivity $(\phi)$ is reduced to 0.96 and 0.8 , respectively, from 0.99. The former parameter value is used in Reifschneider et al. (2015). The latter value is consistent with the estimate of Chang et al. (2002), who use micro-level data from 1953-1997. It is, however, questionable whether the estimate of Chang et al. (2002) is relevant for recessions. The assumption that $\phi=0.8$ does not generate a hysteresis-like response of output, because productivity converges rapidly back to the initial steady state $\left(0.8^{20} \approx 0.01\right)$. This is inconsistent with the empirical evidence showing that recessions have permanent or highly persistent effects on output.

Welfare multipliers depend crucially on the persistence of productivity: In the case where $\phi=0.8$ the welfare multipliers turn negative. A fall in the persistence of productivity has a sizable effect on NPVM, and in the case of $\phi=0.8$, it falls to 1.2. The positive welfare multipliers require that fiscal expansion limits the damage of a recession to the long-term level of output to the extent that it crowds in private activity in the medium and long term for a sufficiently long time. We conclude that a high persistence of productivity is needed for the positive welfare effects. Accommodative fiscal policy makes sense only if the economy is subject to hysteresis or hysteresis-like effects.

In international macroeconomics, results may be sensitive to the crosscountry substitutability $(\sigma)$. Feenstra et al. (2014) find that it could be between 3 and 4 . In an alternative setup, presented in row 6 , we increase $\sigma$ to 3 . This increases the welfare multipliers.

In row 7 , the persistence parameter of the fiscal shock $\left(\rho^{G}\right)$ is increased from 0.75 to 0.9 , while in row 8 it is reduced to 0.6 . We observe a small increase in the output and welfare multipliers in a case where the persistence parameter is low. This is opposite to the result of Rendahl (2016). He finds that the welfare multipliers turn negative in the case where the duration of a fiscal shock is short, relative to the duration of the zero lower bound. In our model, a short-lived fiscal expansion causes a bigger bang for the buck, because it mitigates the fall in productivity and output the most effectively.

\subsubsection{Complementarity between Private and Public Consumption}

Results may depend on the model chosen as a baseline. Next we assume a utility function in which private and public consumption are complements. This affects the response of private consumption and output (Ganelli and Tervala 2009). In the complementarity case, private consumption may rise 
in response to a fiscal shock, which affects welfare multipliers. The utility function, equation (1), is now replaced with

$$
U_{t}(z)=E_{t} \sum_{s=t}^{\infty} \beta^{s-t} \epsilon_{s}^{T P}\left[\log \left(C_{s}+\kappa G_{s}^{C}\right)-{\frac{\left(\ell_{s}(z)\right)^{1+\frac{1}{\varphi}}}{1+\frac{1}{\varphi}}}+\chi \log G_{s}^{C}\right] .
$$

$\kappa$ is the marginal rate of substitution between private and public consumption. A positive (negative) $\kappa$ implies that public and private consumption are Edgeworth substitutes (complements). We focus on the case of complementarity and assume that $\kappa$ is negative. As in Ganelli and Tervala (2009), we assume that public consumption also has a separable utility impact through the term $\chi \log G_{s}^{C}$ so that the marginal utility of public consumption is always non-negative.

The household's optimality conditions are now:

$$
\begin{gathered}
\beta\left(1+i_{t}\right) E_{t}\left(\frac{\epsilon_{t+1}^{T P} P_{t}\left(C_{t}+\kappa G_{t}^{C}\right)}{\epsilon_{t}^{T P} P_{t+1}\left(C_{t+1}+\kappa G_{t+1}^{C}\right.}\right)=1, \\
\ell_{t}(z)=\left(\frac{w_{t}}{\left(C_{t}+\kappa G_{s}^{C}\right) P_{t}}\right)^{\nu} .
\end{gathered}
$$

Equation (19) implies that the household smooths effective consumption, defined as $C_{t}+\kappa G_{t}^{C}$. Equation (20) shows that the labor supply depends on effective consumption. When $\kappa$ is negative, an increase in $G_{t}^{C}$ increases the marginal utility of private consumption, which increases the labor supply.

Substituting the first-order approximations of equation (18) to equation (15) yields

$$
\begin{aligned}
\lambda_{t}= & 100 \times\left[\operatorname { e x p } \left(( 1 - \beta ) \left(\sum_{s=t}^{\infty} \beta^{s-t}\left(\hat{C}_{s}^{F E}-\left(\ell_{0}(z)\right)^{1+1 / \nu} \hat{\ell}_{s}^{F E}+(\kappa+\chi) \hat{G}_{s}^{C, F E}\right)\right.\right.\right. \\
& \left.-\left(\sum_{s=t}^{\infty} \beta^{s-t}\left(\hat{C}_{s}^{W F E}-\left(\ell_{0}(z)\right)^{1+1 / \nu} \hat{\ell}_{s}^{W F E}+\left((\kappa+\chi) \hat{G}_{s}^{C, W F E}\right)\right)\right)-1\right]
\end{aligned}
$$

The model is otherwise identical. We set $\kappa$ to -0.4 , based on Iwata's (2013) estimate. We set $\chi$ such that the overall weight of public consumption $(\kappa+\chi)$ relative to private consumption is equal to $\nu$ (we set $\chi$ to 0.8 in case where $\nu=0.4$ ). Then the direct welfare effect of public consumption is comparable in different versions of the model. Welfare multipliers do not remain the same, because complementarity affects private consumption and the labor supply.

Table 4 shows that multipliers in the complementarity case; the numbers in parentheses show the baseline results. In the absence of hysteresis, 
the difference in results compared with the baseline case is that now we observe higher output multipliers. In the complementarity case, a rise in public consumption increases the marginal utility of private consumption. This increases the labor supply, and output, compared with the baseline case. Table 4 shows that the welfare multipliers are (virtually) the same. An increase in private consumption, when compared with the baseline case, increases welfare. This effect is, however, almost completely offset by the welfare loss caused by an increase in the labor supply. Therefore, the welfare multipliers remain practically the same.

\section{Table 4: Multipliers: Complementarity Case}

\begin{tabular}{|c|c|c|c|c|}
\hline \multirow{2}{*}{$\begin{array}{l}\text { Cumul. } \\
\text { multiplier }\end{array}$} & \multirow{2}{*}{$\begin{array}{l}\text { Net present } \\
\text { value multipl. }\end{array}$} & \multicolumn{3}{|c|}{ Welfare multiplier } \\
\hline & & $\begin{array}{c}\kappa+\chi=0 \\
(\nu=0)\end{array}$ & $\begin{array}{c}\kappa+\chi=0.4 \\
(\nu=0.4)\end{array}$ & $\begin{array}{c}\kappa+\chi=1 \\
(\nu=1)\end{array}$ \\
\hline \multicolumn{5}{|c|}{ Without hysteresis } \\
\hline $1.0(0.7)$ & $1.1(0.8)$ & $-1(-1)$ & $-0.6(-0.6)$ & $-0.03(-0.02)$ \\
\hline \multicolumn{5}{|c|}{ With hysteresis } \\
\hline $1.9(1.4)$ & $6.4(4.5)$ & $3.5(2.2)$ & $3.8(2.6)$ & $4.3(3.2)$ \\
\hline
\end{tabular}

Table 4 shows that complementarity increases welfare multipliers in the presence of hysteresis. In the complementarity case, a rise in public consumption increases the labor supply, compared with the baseline case, in the short term. This limits the damage of a recession to long-term productivity and, thus, output. Therefore, we conclude that the finding that the welfare multiplier of fiscal policy is positive (negative) in the presence (absence) of hysteresis is robust to the introduction of complementarity between public and private consumption.

\section{Conclusions for Economic Policy}

Empirical studies support the hysteresis hypothesis, according to which recessions have permanent effects on the level of output. The relationship between recessions and the equilibrium level of output is inadequately modeled in DSGE macroeconomics. We presented a DSGE model that incorporates a link between recessions and potential output. Fatas and Summers (2016b) and Yellen (2016) argue that hysteresis can change the way economists think about fiscal policy.

Our results suggest that the detrimental effects of fiscal consolidation in weak economic conditions, where hysteresis is relevant, are considerable. Gechert et al. (2015) estimate that cumulative discretionary fiscal consolidation measures in the euro area in $2011-2013$ were $3.9 \%$ of output ( $2 \%$ in 
$2011 ; 1.3 \%$ in 2012 and $0.6 \%$ in 2013). This estimate and our results on the effects on output and TFP imply that the euro area's fiscal consolidation reduced output and TFP by $4.0 \%$ and $0.9 \%$, respectively, relative to the noconsolidation baseline in 2013. Figure 5 shows that TFP fell in the recession of the $2010 \mathrm{~s}$ and it was $1.1 \%$ below trend in $2013 .^{8}$ In addition, output was $4.8 \%$ below the trend in 2013. Accordingly, fiscal consolidation may explain the majority of TFP's and output's deviation from the trend in 2013. In addition, hysteresis implies that the damage of fiscal consolidation is not limited to the short term because of its substantial medium- and long-term effects.

Furman (2016) says that the new view of fiscal policy is that discretionary fiscal policy can be a useful complement to monetary policy in a world with low interest rates that limit conventional monetary policy. Reifschneider et al. (2015) study the implications of hysteresis for monetary policy and find that optimal monetary policy becomes more accommodative in the presence of hysteresis. Our findings suggest that accommodative fiscal policy becomes desirable even in recessions where the central bank does not face the zero lower bound-when the economy is subject to hysteresis effects; accommodative fiscal policy is not desirable in the absence of hysteresis due to negative welfare multipliers. Our findings and those of Reifschneider et al. (2015) indicate that hysteresis has more profound implications for fiscal policy than to monetary policy.

\section{References}

[1] Anzoategui, D., D. Comin, M. Gertler and J. Martinez, 2016. Endogenous technology adoption and R\&D as sources of business cycle persistence. NBER Working Paper No. 22005.

[2] Auerbach, A. J. and Y. Gorodnichenko, 2012. Measuring the output responses to fiscal policy. American Economic Journal: Economic Policy $4,1-27$.

[3] Ball, L. M., 2014. Long-term damage from the Great Recession in OECD countries. European Journal of Economics and Economic Policies: Intervention $11,149-160$.

\footnotetext{
${ }^{8}$ Data are from the Conference Board's (2016) total economy database. The euro area GDP and TFP were aggregated for the original 11 euro area countries (i.e. excluding Greece). The (slightly) time varying country weights were calculated as GDP weights based on constant price GDP in 1990 US-Dollars (converted at Geary Khamis PPPs).
} 
[4] Bergin, P. R., 2006. How well can the new open economy macroeconomics explain the exchange rate and current account?. Journal of International Money and Finance 25, 675-701.

[5] Bilbiie, F. O., T. Monacelli and R. Perotti, 2014. Is government spending at the zero lower bound desirable?. NBER Working Paper No. 20687

[6] Blanchard, O. J., and L. H. Summers 1986. Hysteresis and the European unemployment problem. NBER Macroeconomics Annual 1986, Volume 1, MIT Press.

[7] Blanchard, O., E. Cerutti, and L. Summers, 2015. Inflation and activity - Two explorations and their monetary policy implications. IMF Working Paper No. 15/230.

[8] Bodenstein, M., C. J. Erceg and L. Guerrieri, 2009. The effects of foreign shocks when interest rates are at zero. Board of Governors of the Federal Reserve System International Finance Discussion Papers No. 983.

[9] Calvo, G. A., 1983. Staggered prices in a utility maximizing framework. Journal of Monetary Economics 12, 383-398.

[10] Chang, Y., J. F. Gomes and F. Schorfheide, 2002. Learning-by-doing as a propagation mechanism. American Economic Review 92, 1498-1520.

[11] Chetty, R., A. Guren, D. Manoli and A. Weber, 2013. "Does indivisible labor explain the difference between micro and macro elasticities? A meta-analysis of extensive margin elasticities. NBER Macroeconomics Annual 2012 27, 1-56.

[12] Clarida, R., J.Galí, and M. Gertler, 2000. Monetary policy rules and macroeconomic stability: Evidence and some theory. Quarterly Journal of Economics 115, 147-180.

[13] Conference Board 2016, Total economy database available at https://www.conferenceboard.org/data/economydatabase/index.cfm?id=27762 (accessed on September 27,2016).

[14] DeLong, J. B. and L. H. Summers, 2012. Fiscal policy in a depressed economy. Brookings Papers on Economic Activity 44, 233-297.

[15] Dong, W. 2012. The role of expenditure switching in the global imbalance adjustment. Journal of International Economics 86, 237-251. 
[16] Everaert, G., F. Heylen and R. Schoonackers, 2015. "Fiscal policy and TFP in the OECD: measuring direct and indirect effects. Empirical Economics 49, 605-640.

[17] Fatás, A. and L. H. Summers 2016. "The permanent effects of fiscal consolidations. NBER Working Paper No. 22734.

[18] Fatás, A and L. H. Summers 2016. "Hysteresis and fiscal policy during the Global Crisis" avalable at http://voxeu.org/article/hysteresis-andfiscal-policy-during-global-crisis (accessed October 19, 2016).

[19] Feenstra, R. C., M. Obstfeld and K. N. Russ, 2014. In search of the Armington elasticity. NBER Working Paper No. 20063.

[20] Furman, J., 2016. The New View of fiscal policy and its application, available at http://voxeu.org/article/new-view-fiscal-policy-andits-application (accessed November 2, 2016).

[21] Gali, J., 2015, Monetary policy, inflation and the business cycle: An introduction to the New Keynesian framework and its applications, 2nd Edition. Princeton, Princeton University.

[22] Ganelli, G. and J. Tervala, 2009. Can government spending increase private consumption? The role of complementarity," Economics Letters $103,5-7$.

[23] Ganelli, G. and J. Tervala, 2016. The welfare multiplier of public infrastructure investment", IMF Working Paper No. 16/40.

[24] Gechert, S. and A. Rannenberg 2014. Are fiscal multipliers regimedependent? A meta regression analysis. IMK Working Paper No. 139.

[25] Gechert, S, A H. Hallett and A. Rannenberg 2015. Fiscal multipliers in downturns and the effects of Eurozone consolidation. CEPR Policy Insight 79 .

[26] IMF 2012, Fiscal Monitor: Balancing Fiscal Policy Risks. Washington $\mathrm{DC}, \mathrm{IMF}$.

[27] IMF 2015, Fiscal Policy and Long-Term Growth. Washington DC, IMF.

[28] Iwata, Y., 2013. Two fiscal policy puzzles revisited: New evidence and an explanation. Journal of International Money and Finance 33, 188-207. 
[29] Keane, M. and R. Rogersson, 2012. Micro and macro labor supply elasticities: A reassessment of conventional wisdom. Journal of Economic Literature 50, 464-476.

[30] Kilponen, J., M. Pisani, S. Schmidt, V. Corbo, T. Hledik, J. Hollmayr, S. Hurtado, P. Júlio, D. Kulikov, M. Lemoine, M. Lozej, H. Lundvall, J. R. Maria, B. Micallef, D. Papageorgiou, J. Rysanek, D. Sideris, C. Thomas and G. De Walque, 2015. Comparing fiscal multipliers across models and countries in Europe. ECB Working Paper No. 1760.

[31] Klein, P., 2000. Using the generalized Schur form to solve a multivariate linear rational expectations model. Journal of Economic Dynamics and Control 24, 1405-1423.

[32] Linnemann, L. G. B. Uhrin, M. Wagner 2016. Government spending shocks and labor productivity. TU Dortmund University Discussion papers SFB 823 No. 9/2016.

[33] Mankiw, G. and M. Weinzierl 2011. An exploration of optimal stabilization policy. Brookings Papers on Economic Activity 42, 209-272.

[34] Martin, R. F., T. Munyan and B. A. Wilson 2015. Potential output and recessions: Are we fooling ourselves?" Board of Governors of the Federal Reserve System International Finance Discussion Paper No. 1145.

[35] McCallum, $\quad$ B., 2001. Software for RE analysis. computer software available at http://wpweb2.tepper.cmu.edu/faculty/mccallum/research.html.

[36] Rabanal, P. and V. Tuesta, 2010. Euro-dollar real exchange rate dynamics in an estimated two-country model: An assessment. Journal of Economic Dynamics and Control 34, 780-797.

[37] Ramey, V. A. and S. Zubairy, 2016. Government spending multipliers in good times and in bad: Evidence from U.S. historical data. Journal of Political Economy forthcoming.

[38] Rawdanowicz, Ł., R. Bouis, K.-I. Inaba and A. K. Christensen, 2014. Secular stagnation: Evidence and implications for economic policy", OECD Economics Department Working Papers No. 1169.

[39] Reifschneider, D., W. Wascher and D. Wilcox 2015. Aggregate supply in the United States: Recent developments and implications for the conduct of monetary policy. IMF Economic Review 63, 71-109. 
[40] Rendahl, P. 2016. Fiscal policy in an unemployment crisis. Review of Economic Studies 83, 1189-1224.

[41] Schmitt-Grohe, S., and M. Uribe, 2007. Optimal simple and implementable monetary and fiscal rules. Journal of Monetary Economics 54, $1702-1725$.

[42] Sims, E. and J. Wolff, 2014. The output and welfare effects of government spending shocks over the business cycle. NBER Working Paper No 19749 .

[43] Song, Z., K. Storesletten and F. Zilibotti, 2012. Rotten parents and disciplined children: A politico-economic theory of public expenditure and debt. Econometrica 80, 2785-2803.

[44] Summers, L. H. 2015. Advanced economies are so sick we need a new way to think about them. available at https://www.ft.com/content/c5a222d7-1724-3004-b3d7-eff58e4c0dc9 (accessed November 3, 2016).

[45] Taylor, J., B, 1993. Discretion versus policy rules in practice. CarnegieRochester Conference Series on Public Policy 39, 195-214.

[46] Tervala, J., 2013. Learning by devaluating: A supply-side effect of competitive devaluation," International Review of Economics \& Finance 27, 275-290.

[47] Uhlig, H., 2010. Some fiscal calculus. American Economic Review 100, $30-34$.

[48] Woodford, M. 2011. Simple analytics of the government expenditure multiplier. American Economic Journal: Macroeconomics 3, 1-35.

[49] World Bank, 2016, Data available online at http://data.worldbank.org/ (accessed April 22, 2016).

[50] Yellen, J. L., 2016, Presentation "Macroeconomic research after the Crisis", At "The elusive 'Great' Recovery: Causes and implications for future business cycle dynamics" 60th annual economic conference sponsored by the Federal Reserve Bank of Boston, Boston, Massachusetts. 
Figure 1: Total factor productivity and GDP in the U.S. (indexes 2007=100), and their projections based on 1990-2007 trend, source: Conference Board (2016)

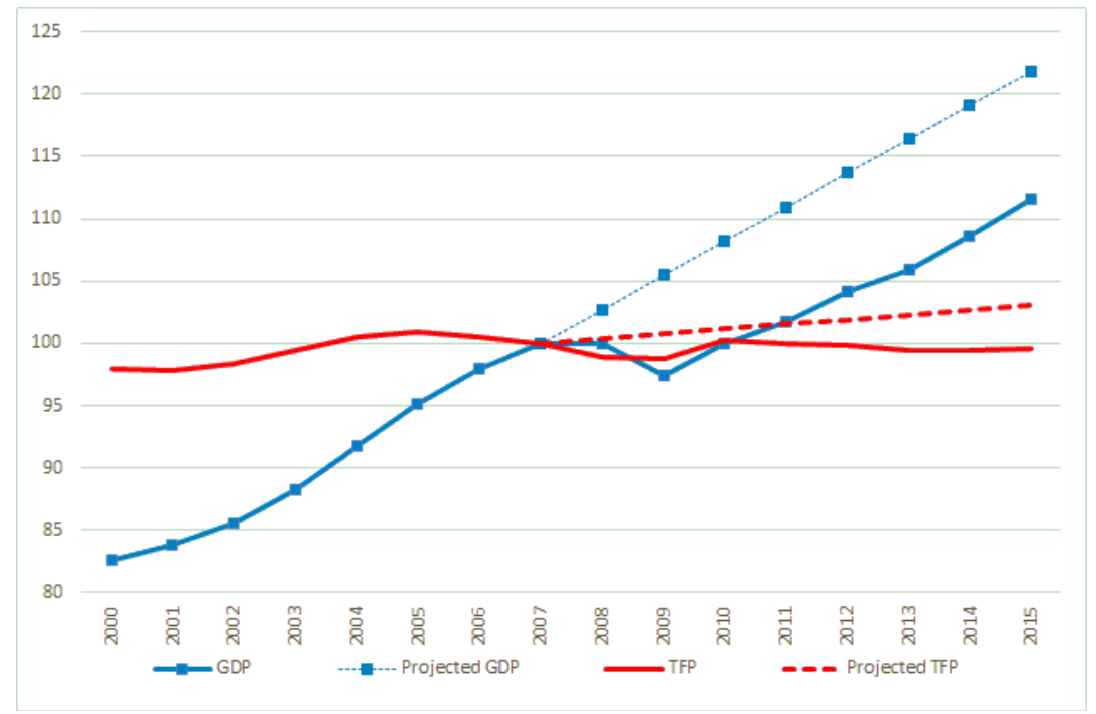

Figure 2: Dynamic responses to a foreign time preference shock without hysteresis
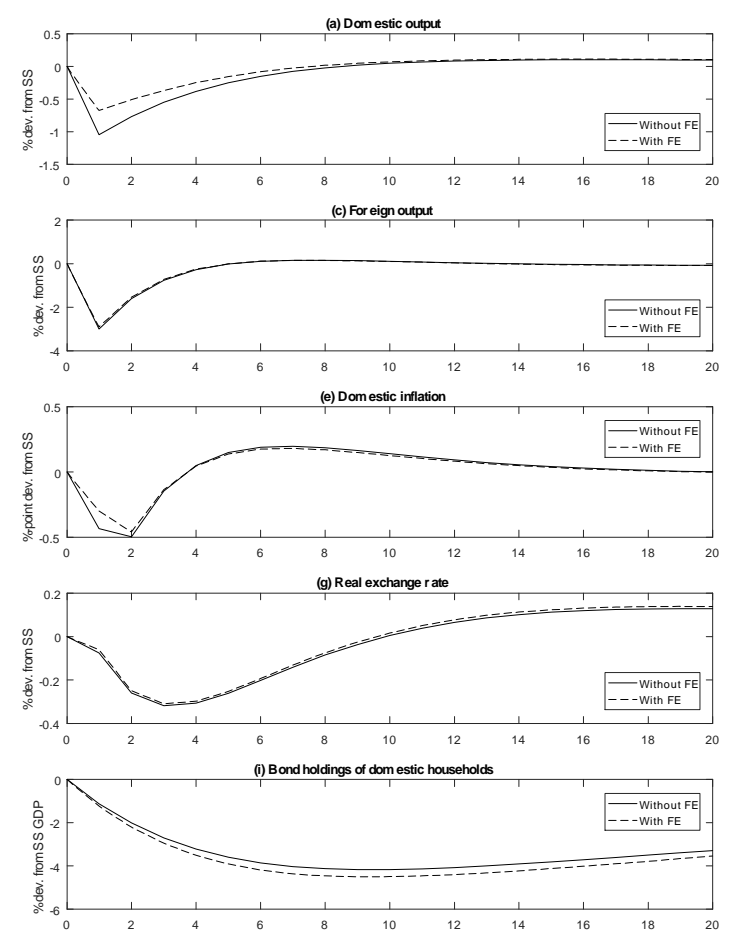

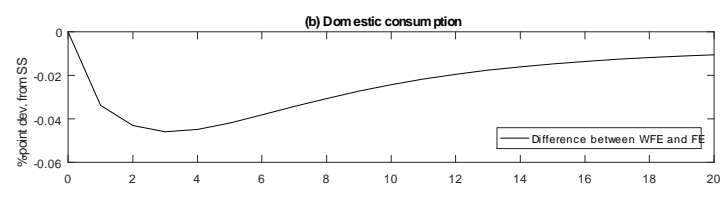

(d) For eign consum ption
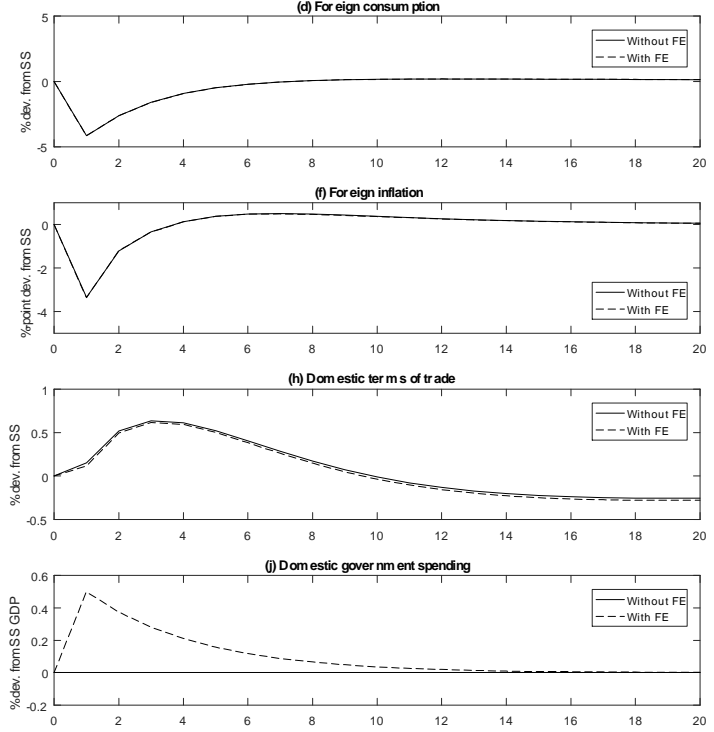
Figure 3: Dynamic responses to a foreign time preference shock in the presence of hysteresis
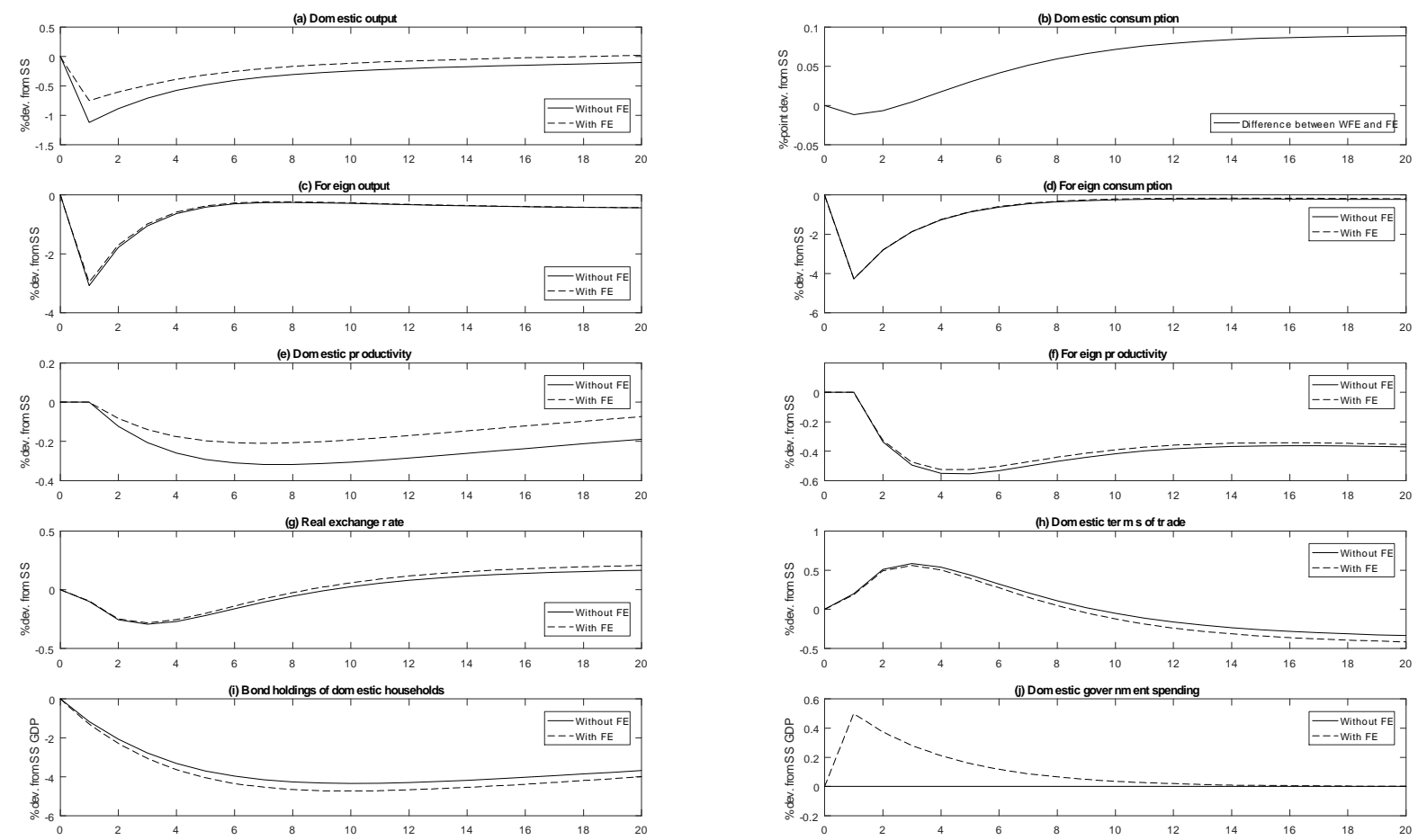
Figure 4: Domestic output without and with hysteresis

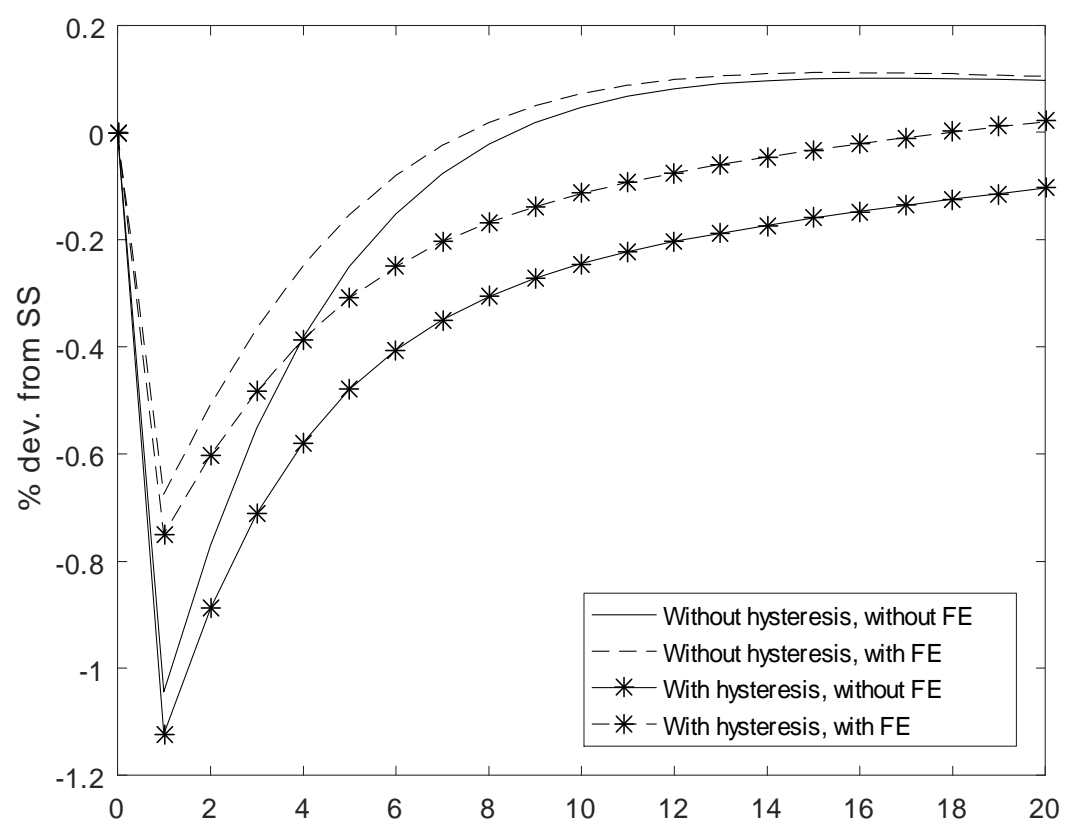

Figure 5: Total factor productivity and GDP in the euro area (indexes $2008=100$ ), and their projections based on 1990-2008 trend, source: Conference Board (2016)

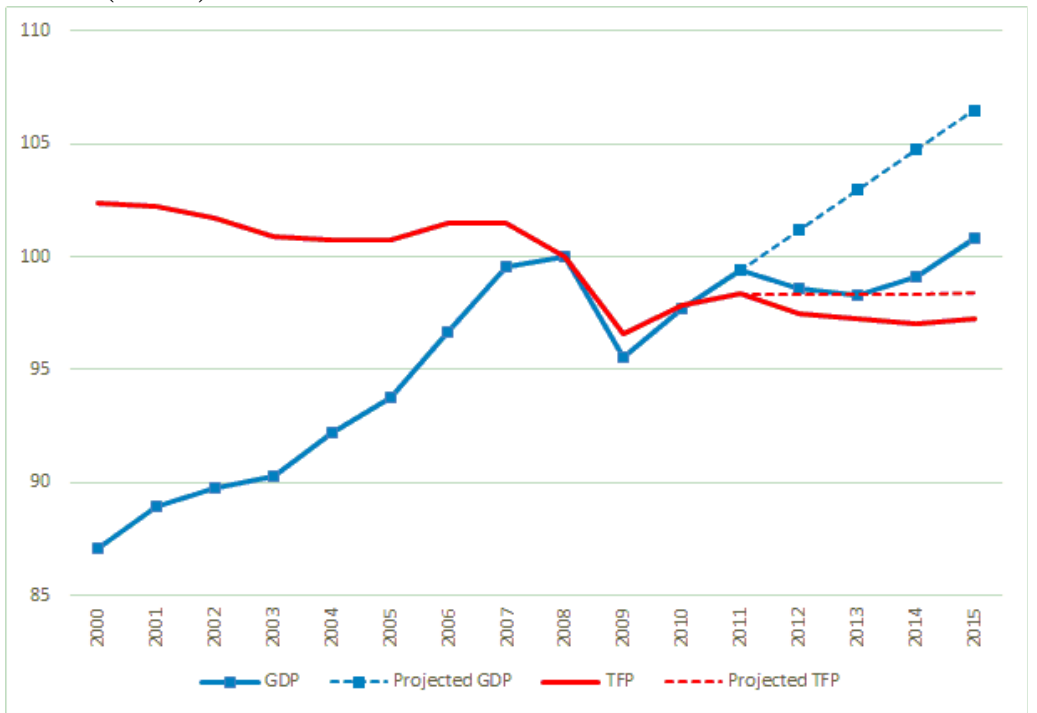

